\title{
A research on transformation of social wellbeing and life attitudes in students from the occupied territories and the demarcation line at relocated higher education institutions from the east of Ukraine
}

\author{
Iryna Trubavina ${ }^{1, *}$, Olena Karaman $^{2, * *}$, Dimitrina Kamenova $^{3, * * *}$, Viktoriia Stepanenko ${ }^{2, * * *}$, and Yaroslava Yurkiv ${ }^{2, \dagger}$ \\ ${ }^{1}$ Department of Socio-humanities subjects, National Academy of the National Guard of Ukraine, 3 Zakhysnykiv Ukrainy Sq., Kharkiv, \\ 61001, Ukraine \\ ${ }^{2}$ Department of Social Pedagogy, Luhansk Taras Shevchenko National University, 1 Gogol Sq., Starobilsk, 92703, Ukraine \\ ${ }^{3}$ Department for Modern Educational Methods, Varna University of Management, 13A Oborishte Str., Varna, 9000, Bulgaria
}

\begin{abstract}
We connect the urgency of the article with the preservation of the integrity of Ukraine in the conditions of military conflict. The article describes the research on transformation of the current state of social wellbeing and life attitudes in students from the occupied territories of Ukraine under conditions of relocated higher education institutions. The goal: to study the transformation in social wellbeing and life attitudes in the mentioned strata of students under conditions of operation of a relocated state higher education institution. The methods: analysis, synthesis, generalization, specification, systematizing, comparison, documentation study, interviewing, mathematics statistics methods. Scientific novelty: theoretical foundations and the essence of reintegration of such students, as well as the measures are determined that facilitate it: information and explanatory work, socio-educational, psychological, pedagogical, socio-economic, and legal ones. It is proved that national-oriented upbringing is the priority in successful reintegration on condition of solving students' problems. The results: the efficiency in the use of the mentioned measures is proved by transformational changes related to overcoming the imbalance between the social wellbeing indicators (the level of life satisfaction, interest in life, general mood) and life attitudes (focus on process, result, freedom) of such students.
\end{abstract}

\section{Introduction}

The authors consider the article as being topical due to:

1. The need in ensuring the conditions for the utmost implementation of the right of student youth from the occupied territories and the demarcation line in the east of Ukraine on education at higher education institutions (HEI). This issue is new for education management.

2. The need in preserving the Ukrainian nation's identity, its unity, patriotic attitudes, and loyalty to the national Ukrainian idea: the United, Indivisible Ukraine by means of education. This requires special, purposeful educational work at HEI which prior did not fulfill such work and did not bear such responsibility before the society and did not fulfill such function and load.

3. The presence in the current Ukrainian society of the migration, new socio-political and economic, and globalization processes; a growth in the volume of

\footnotetext{
*e-mail: trubavina@gmail.com

**e-mail: karaman.olena.lnu@gmail.com

***e-mail: dimitrina.kamenova@vumk.eu

****e-mail: viktoriyalnu@gmail.com

†e-mail: yurkiv.yara@gmail.com
}

information flow observed on the background of social instability and new communities formation lead to changes in the mode and way of life of many categories and strata of population, their working conditions, and their ideas of culture, world outlook, way of life, the values system. The corresponding processes under conditions of the military conflict in the east of Ukraine, the tension and disinformation make urgent the need in processes of preserving the national identity, uniqueness, health, in critical thinking and sustainable society formation as protective mechanisms in the face of threat to national security $[1,2]$. These and other aspects are part of the work of academic groups' curators and socio-psychological services at HEIs, but methodologies and recommendations concerning the students from the occupied territories and the demarcation line have not been developed yet.

4. The youth is especially vulnerable category in the aspect of correctness / incorrectness of life priorities placement, which is determined by their insufficient life and social experience. This, as proved by a research [3], complicates the building-up of a clear prognosticated estimation concerning the position of the state, it often prevents the youth from making a correct choice, causing numerous contra- 
dictions in their life strategies and disrupting their inner logic and wholesomeness. Besides, a young person's social wellbeing is one of the most important constructs that determines different aspects of a person's relations with the world, their success, assimilation of social skills and norms, and valuesand-sense self-determination within these norms [46]. The goals and tasks of educational, social, and psychological work in this direction are not determined for a HEI, in particular for those working with the students from the demarcation line and the occupied territories.

5. Students are the social group, which due to its formal organization and common values, a subculture, becomes a radical motive power of society (the 2013 pro-European Maidan in Kyiv was triggered by students' protestations and their struggle for European values), therefore it is important to direct students' movements at peaceful settling of conflicts, to know students' attitudes, bring them up on patriotism and the culture of peace that again requires special work with such students, overcoming their negative life experiences wherein such students saw manifestations of war culture.

6. The students from the east of Ukraine, particularly from the occupied territories and the demarcation line, are greater patriots than their peers from other territories, for they have made their choice in favor of remaining the citizens of Ukraine, having lost for this sake social and material benefits (housing, parents nearby, friends), but as a result of this they experience bigger problems with socialization and the necessity in satisfying basic needs. All the children in the east of Ukraine have a psychological, and sometimes a physical, trauma, with which they live (shellings, deaths, wounds, bombardments, hunger, lack of medical assistance, loss of home, etc.), they often perform the roles of adults in the family (of the absent father or mother), they have lost childhood prematurely and taken care of other family members (grandparents, brothers or sisters), they have learnt family economy and taking care of and serving themselves early [7]. This determines premature adulthood in students and inflicts additional physical, psychological, social, economic load on them. Moreover, the problems of adapting and integrating into a new education environment, a students' hostel add up to this, which means practically complete breaking of social ties they had before entering Ukrainian HEIs, the problems of socialization in a group of peers who have not experienced occupation, internal displacement, and psychological traumas. All this reflects on inner world, the values, behavior, and learning of students from the occupied territories and the demarcation line at HEIs in the east of Ukraine. This calls for separate research and special work with such students.
7. As research prove [8], the difficult socio-political situation in the east of Ukraine causes the need in broadening the lines of counteracting its negative consequences through activation of multilevel and multifaceted information, socio-psychological, migration, and other influences that act as one of the modes of ensuring social security and reintegration measures. This problem gains special urgency under conditions of operation of a relocated HEI, which, unlike common HEIs face additional challenges connected with solving the problem of reintegration of students at the institution simultaneously with the issues of forming the due conditions for such reintegration in the circumstances of their relocation. The Ministry of Education and Science of Ukraine (MES) does not have statistics as to the number of children from the occupied territories who enter HEIs through the general procedure by passing school-leaving certification testing. As for the simplified procedure of entering HEIs, it was introduced in 2016 and supposed that children and youth from the occupied territories can enter certain education institutions whose list was limited [9]. In 2020, application was made possible to any education institution [10]. Overall, in 2019, 1600 persons entered HEIs through the "Donbass Ukraine" education center [11], in 2018 - 1522 people. In 2017, there were 1346 of them, and in $2016-$ 855 people [12]. Therefore, the number of children and youths from the occupied territories involved into the Ukrainian education system keeps growing, which attests to their stable support of Ukrainian state, patriotic choice, and requires to build up work with them at HEIs concerning their integration and adaptation, as well as solving the socialization problems. Nevertheless, at the majority of HEIs, this work is currently at the stage of intuitive search for ways and methods and is problem-oriented at solving present-day issues.

8. The topicality and at the same time insufficient development of this research problematics in scientific works should be noted. The regional, social and group peculiarities should be taken into account when studying student youth' life plans and orientations under conditions of Ukrainian society and statehood's current evolvement, according to M. Alyohin [3]. Meanwhile, there has been no such research concerning the category of HEI students in question. S. Gorbatiuk turns attention to the need in estimating the social wellbeing level in population, the indicators of which enable evaluating the state of social sphere objectively [13]. Efficient public and social management is based on diagnostics of population's problems and needs. For HEI, it is important to be aware of these problems and those of different categories of students, including internally displaced persons and those from the occupied territories and the demarcation line. This would enable conducting target work with such students. 
Elucidation of the issues of children's and youth' life perspectives and expectations, their social and psychological wellbeing in conditions of threats and challenges is represented in works by foreign researchers: V. Gil-Rivas et al. [14, 15], G. Kerestes [16], L. Saupe et al. [17], R. Seginer [18], L. Stark et al. [19] etc. Reintegration of young people into society after war in various aspects (political, social, economic, psychological, etc.) was researched by A. Honwana [20], A. Bryden \& V. Scherrer [21], A. Giustozzi [22], M. Humphreys \& J. Weinstein [23], et al. Nevertheless, their works were not related to students and work immediately with them in the direction of values, social wellbeing, life attitudes. From the position of directedness and personality's ideas formation, of scientific interest is the study by D. Matyukhin [24], where he views young people's social attitudes as components of lifestyle that represent in themselves a certain persistent and fixed construct, which gives stability and direction to a person's activity and is manifested in his/her social interaction and behavior. This conclusion is important in the context of ensuring sustainable development of a personality, a community, and the society. Lifestyle in conditions of learning at a relocated HEI by the category of students in question was not researched either. Therefore, theoretic and empirical researches within the context of the problem of student youth's reintegration into relocated HEIs and their social wellbeing and life attitudes are virtually non-existent, which was the reason for organizing such a research on the basis of the Luhansk Taras Shevchenko National University. Among other things, the university scientists started science-and-research activities concerning comparing the data as to the hierarchy and value orientations of the Donbas youth obtained in the course of interviewing in 2013 (prior the conflict in the east) and in 2018 (during the conflict) [25]; comparative analysis of the views of young people from temporally occupied territories on the events in Ukraine in $2014-2019$ [26]; determining the conflictability level of social environment in Luhansk area and teachers' readiness for influencing processes of reconciliation and establishing peace [27]], and others. In previous researches of the studied issue, the authors accentuated on the need in forming and demonstration in everyday life the behavior based on the culture of peace and accentuating its advantages over the behavior based on the cult of war, demonstrating negative consequences of behavior based on the culture of war for every person, community, country of the world, and the planet [28]; a research was undertaken concerning the determining a personality's socio-psychological deformation indicators under conditions of the hybrid war [29]; the social characteristic of children and youths as victims of the hybrid war in the east of Ukraine was presented [30]. In the context of society globalization and informatization processes, a research of so- cial wellbeing and life attitudes of student youth are of special topicality in society and of scientific novelty in the theory of general and social pedagogy and social work, because the conflict in Donbas is one of the crucial challenges to the national security of Ukraine [31], it dehumanizes social relations, causes estrangement, leads the society to spiritual and moral regress [2]. It should be noted that the authors' research on social wellbeing and life attitudes of students from the occupied territories and demarcation line is conducted not in terms of comparing them prior and during the military conflict, but in terms of their transformation immediately under conditions of a relocated HEI operation directed at reintegration of the youth from these territories into the Ukrainian environment. Departing from the aforementioned, the goal of this article is a research on transformation of social wellbeing and life attitudes in students from the occupied territories of the east of Ukraine and demarcation line under conditions of operation of a state higher education institution (on the example of the Luhansk Taras Shevchenko National University) in the context of their reintegration into the Ukrainian environment.

The tasks of the research:

1) to study the current state of social wellbeing and life attitudes in eastern Ukraine HEI students from the occupied territories and the demarcation line at the stage of their admission to a relocated higher education institution,

2) to determine theoretical foundations and the essence of the notion of reintegration in work with students from the occupied territories and the demarcation line under conditions of a relocated HEI

3) to generalize from practical work the measures aimed at successful reintegration that make an impact on social wellbeing and life attitudes of students from the occupied territories and the demarcation line under conditions of a relocated HEI,

4) to perform an estimation of transformational changes in social wellbeing and life attitudes of the eastern Ukraine HEI students from the occupied territories and the demarcation line following the introduction of the mentioned measures under conditions of a relocated HEI operation.

\section{Methodology}

In the course of the research, the following methods were applied: analysis, synthesis, generalizing, specifying, systematizing, comparison, documentation study, interviewing, mathematic statistics for comparing, evaluation and interpreting the obtained results of the initial and final diagnostics as to the transformation of social wellbeing and life attitudes of students from the occupied territories and 
the demarcation line. The students' life attitudes were determined in accordance with the methodology of determining a personality's socio-psychological attitudes by O. Potyomkina [32]; the social wellbeing index - by the "Satisfaction with life" test in N. Panina's adaptation [33]. The students' life attitudes were determined departing from the supposition that a personality's attitude is the stance of treating a goal or tasks that is manifested in selective orientation at and readiness for activities that facilitate accomplishing them [34]. The methodology [32] enables determining the extent of a personality's socio-psychologic attitudes directedness at "process - result", "altruism - egotism", "freedom" - "power", "work" - "money". Because social wellbeing includes an individual's subjective feelings as to his/her satisfaction with different aspects of their activities $[35,36]$, is associated with the integral satisfaction with life [37], and is viewed as the reflection of life quality and the completeness of measuring it [38], to determine its index, the authors applied the "Satisfaction with life" (SWL) test as adapted by N. Panina [33]. The test enables determining the general level of satisfaction with life (social wellbeing) that includes such its aspects as interest in life, determination, commitment and consistency in achieving the goals, correlation between the set and the achieved goals, evaluation of one's own traits and actions, and general mood background.

The research was conducted at the base of the Luhansk Taras Shevchenko National University within the scientific project of "Socialization of pupils and students youth from the east of Ukraine under the hybrid war conditions in Donbas" (2018 - 2020), state registration number 0118 U003335 [39].

211 students who entered the university through the "Donbas - Ukraine" educational center took part in the experiment, 106 of them being from the occupied territories and the demarcation line, and the place of residence of the other 105 students was in the safe zone. In the course of the experiment, results interpretation was made with the use of the Statistica 12 program. The research meets the requirements of research ethics.

\section{Results}

In 2014 Luhansk Taras Shevcheko National University being in the epicenter of terrorist groups' crimes, suffered repressions, and seizure and ruining its premises. In order to continue full-fledged activities, the university was relocated to the town of Starobilsk. The training process organizing at the university is maintained on the principles of mobility, flexibility, and constant search for new efficient forms of interacting with students, ensuring education quality, forming in students a balanced life attitude, the ability to perceive, obtain, apply, and broaden the necessary experience [40]. According to the Development Strategy of the university, its mission is to ensure training of competitive specialists on the basis of organic unity of high-quality student-centered training, scientific work, creativeness and patriotism development, and future reintegration of the occupied territories [41].
Starting since 2016, Luhansk Taras Shevchenko National University performs admission of school-leaving applicants from the east of Ukraine, uncontrolled territory, and the demarcation line through the "Donbas - Ukraine" educational center. Thus, in 2016, the number of such applicants was 149 people, in 2017 - 224, in $2018-219$, and in 2019 - 191 people. Correspondingly, the total number of students during those years amounted to 783 people from the uncontrolled territory and the demarcation line. As of 13.01.2020, the number of students from the uncontrolled territory who entered through the "Donbas Ukraine" educational center and are studying at the university is 433 people [42].

In order to determine the current state of social wellbeing and life attitudes in students from the occupied territories and the demarcation line, in December 2018 diagnostic-and-analytical work was conducted, in the course of which the data obtained were compared by these indicators regarding the students from the occupied territories and the demarcation line $(n=106)$ and the students whose residence was in the safe zone $(n=105)$.

The verification of all distributions in the social wellbeing indicators in the studied groups by the Shapiro-Wilk and Kolmogorov-Smirnov criteria demonstrated that they do not obey the Gauss law, which determined the use of non-parametrical methods of mathematic statistics. By means of Mann-Whitney's $U$-criterion, all social wellbeing indicators were compared for students from the occupied territories and those from safe zones. Results of the initial diagnostics by these indicators are presented in table 1.

The data obtained attested to the prevalence in students from the occupied territories and the demarcation line of a lower level of social wellbeing indicators compared with those in the students who reside in safe zones $(U=4515,5$, $z=2,37, p=0,02)$. Besides, they demonstrate lower indicators in the scales of "interest in life" ( $U=4430,5, z=2,61$, $p=0,01)$ and "generalized mood background" ( $U=3356$, $z=4,98, p<0,001$ ), which attested to a lesser extent in enthusiasm, optimism, interest in everyday life, and getting pleasure from life demonstrated by them. This means, that the load of adult problems and psychological traumas, the socialization and adaptation problems continue influencing these students. As to the social wellbeing indicators level for students who reside in safe zones, it should be noted that they coincide with those obtained in the research conducted by I. Galyan and dedicated to the study of the structure and determinants of satisfaction with life in pedagogues-to-be [43]. Therefore, special work at HEIs with students from the occupied territories and the demarcation line is needed.

The results of the initial diagnostics of sociopsychological attitudes to "process - result", "altruism egoism", "freedom - power", "work - money" in the studied groups are presented in figure 1. Thus, in both groups of students the orientation at altruism, work, and freedom prevails. As to the "process - result" life attitudes, the higher indicators of the attitude to process than those to result were demonstrated by students from the occupied territories and the demarcation line. It should be noted that 
Table 1. Results of initial diagnostics of comparing social wellbeing in the students from the occupied territories and the demarcation line (group II) and the students from safe zones (group I)

\begin{tabular}{|c|c|c|c|c|c|c|c|c|c|}
\hline Indicator & $\begin{array}{c}\text { Rank } \\
\text { Sum } \\
\text { group I }\end{array}$ & $\begin{array}{c}\text { Rank } \\
\text { Sum } \\
\text { group II }\end{array}$ & $U$ & $z$ & $p$-value & $\begin{array}{c}z \\
\text { adjusted }\end{array}$ & $p$-value & $\begin{array}{l}\text { Valid } N \\
\text { group I }\end{array}$ & $\begin{array}{l}\text { Valid } N \\
\text { group II }\end{array}$ \\
\hline $\begin{array}{l}\text { The satisfaction } \\
\text { with life level }\end{array}$ & 12179,5 & 10186,5 & 4515,5 & 2,37 & 0,02 & 2,37 & 0,02 & 105 & 106 \\
\hline Interest in living & 12264,5 & 10101,5 & 4430,5 & 2,56 & 0,01 & 2,61 & 0,01 & 105 & 106 \\
\hline Consistency in goals & 11187 & 11179 & 5508 & 0,13 & 0,9 & 0,13 & 0,9 & 105 & 106 \\
\hline $\begin{array}{l}\text { Goals correlation } \\
\text { Positive self- }\end{array}$ & 11117,5 & 11248,5 & 5552,5 & $-0,03$ & 0,98 & $-0,027$ & 0,98 & 105 & 106 \\
\hline $\begin{array}{l}\text { estimation } \\
\text { Generalized mood }\end{array}$ & 10924,5 & 11441,5 & 5359,5 & $-0,46$ & 0,64 & $-0,47$ & 0,64 & 105 & 106 \\
\hline background & 13339 & 9027 & 3356 & 4,98 & 0,000 & 5,05 & 0,00 & 105 & 106 \\
\hline
\end{tabular}

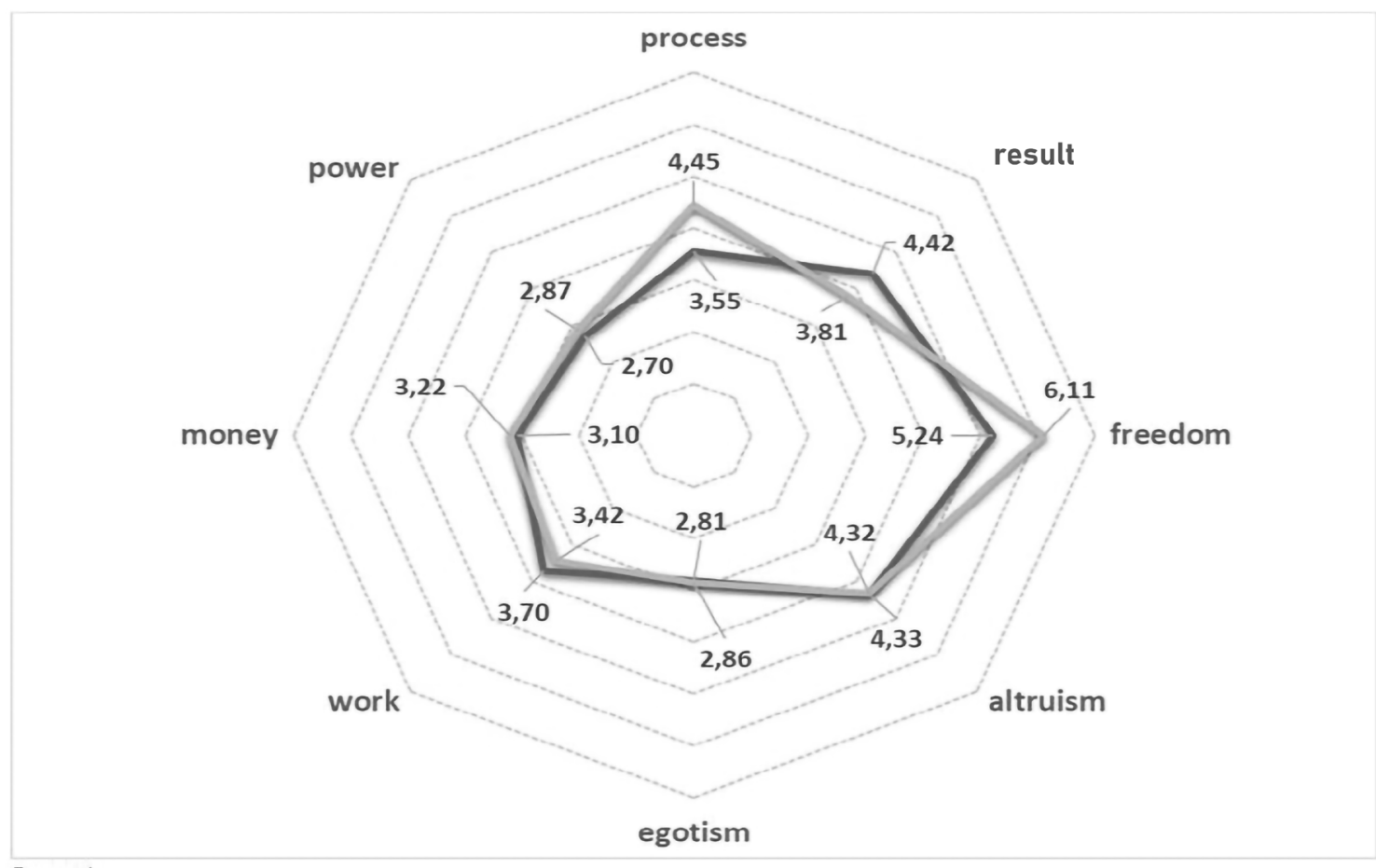

extent in manifestation of life attitudes in students who reside in safe zones

extent in manifestation of life attitudes in students from the occupied territories and the demarcation line

Figure 1. Indicators of life attitudes in students from the occupied territories and the demarcation line and students residing in safe zones

the correspondent attitude is characterized by such negative traits as students' frequent failure to hand in their works in time, their low efficiency, and low academic performance. In students residing in safe zones, on the contrary, higher indicators of the attitude to result were observed. The authors explain this by the fact that the students from safe zones do not have those problems and needs which distract students from the occupied territories and the demarcation line from learning in their everyday life.

In students from the occupied territories and the demarcation line, higher indicators of the attitude to freedom than that to power were observed. In its turn, in students from the safe zones, a similar tendency was observed, but the attitude to freedom as a need was manifested to a lesser extent, which attests to the need of the students from the occupied territories and the demarcation line in realization of freedom of choice and behavior compared with the students from safe zones, who have a possibility of realizing this need. This conclusion on domination of the attitude to freedom over that to power among the student youth is confirmed by results of other scientists' researches $[24,44]$.

Verification of all distributions of life attitudes indicators in the studied groups for normality by means of the Shapiro-Wilk and Kolmogorov-Smirnov criteria also revealed that they do not obey the Gauss law. Consequently, non-parametric statistical methods were applied 
to confirm significance in the difference between the mentioned indicators in the studied groups. By means of the Mann-Whitney's $U$-criterion this difference was statistically confirmed in the indicators of directedness at free$\operatorname{dom}(U=3953 ; z=-3,68, p<0,001)$, process $(U=4072,5$, $z=-3,41, p<0,001)$ and result $(U=4599,5, z=2,22, p<0,03)$ - table 2, that attested to the correctness of the reached conclusions. Therefore, the life satisfaction level, interest in life, and the general mood background of students from the occupied territories and the demarcation line became the main criteria in the research of transformation of their social wellbeing in the context of their integration into Ukrainian environment, while focus on process, result, and freedom - the criteria of life attitudes transformation.

Attaining the corresponding changes, the essence of which is overcoming the imbalance between the indicators of social wellbeing and life attitudes of students from the occupied territories and the demarcation line as opposed to those living in the safe zone, is possible on condition of conducting the reintegration on the level of a HEI and the community. In this case, the definition of the essence of reintegration in work with students on the level of a relocated HEI is the key one to the authors' research:

Reintegration is uniting of anything that has fallen apart, was disconnected and is restored on new principles, foundations [45]. Thus, a far-reaching goal of reintegrating students through the education system of Ukraine is restoration of territorial, social, economic, and political wholesomeness of the country, overcoming of separation and conflicts. In practice, for a HEI it means priority of educational work, the national idea of Ukraine that are performed along with forming social and economic conditions for internally displaced students, improvement of their life quality.

It is noted in the Recommendations concerning reintegration of the population that suffered from the conflict in Donbas and restoration of the just peace, developed by the International Civil Society Platform "CivilM+" that currently, the Office of the UN High Commissar for the Refugees Affairs and the International Migration Organization consider reintegration process more often in the context of return of displaced persons or refugees. As to Ukraine, it is still impossible to speak about IDPs returning to the places of their previous residence, which is why reintegration can be defined as a process that includes a gradual formation of conditions that enable the population that has suffered from the conflict, to enjoy their social, economic, civil, and political rights. The notion of reintegration supposes elimination of the difference in status and rights between the communities that have suffered from the conflict and the population from the safe zone [46]. This means that national education alone is not enough for successful reintegration of students from the occupied territories and the demarcation line. It should be also sustained with social, economic, political measures, with forming varied conditions for realization of all human rights.

The term of "safe reintegration", which is currently used in the documents related to the conflict in the east of Ukraine, means a "processes in forming and implementing policies, strategies, and actions of government that are directed at attaining of lasting peace on the basis of restoration of territorial integrity and sovereignty of Ukraine at temporally occupied territories, protection of people's rights, satisfying their socio-humanitarian needs, restoration of democratic institutions' operation, ensuring national unity and social cooperation, preserving and strengthening humanitarian contacts between people who live on the territory of Ukraine controlled by the government and at the temporally occupied territory" [47]. Therefore, this supports the authors' conclusion that along with prioritized national upbringing of students, other measures concerning their successful reintegration are needed as well. Safe reintegration is based on the complex approach to solving this problem.

It should be noted separately, that the applicants are mostly aged $16-17$, for whom family is the best precondition of upbringing and development in accordance with the UN Convention on Children's Rights [48]. Therefore, a HEI has to ensure family relations for these children in their reintegration and adaptation to new conditions of life, to form conditions for daily family relationships, and ensure their connection with families and parents for students' successful socialization and development, as well as their parents' reintegration on the territory of Ukraine later on. It is family that gives the feeling of being protected and safety, parents are responsible for fulfilling the children's rights and bear responsibility for them, make decisions concerning their lives and health, etc.

Thus, a HEI influences not only children's and youth's reintegration, but their parents' as well, indirectly, through children, which generally facilitates the dialogue, overcoming conflicts, and reunification of families, children and parents on Ukrainian soil as a long-term goal of a HEI's work.

In the Guidelines on children's reintegration, it is stressed that families should always be in the focus of all reintegration processes and participate in making decisions at each stage of implementing the program. It is necessary to utilize their advantages and remove disadvantages. This is the resilience approach. Also, it is needed to involve competent personnel in work on social protection of children in the reintegration process, provision of services and social guidance, cooperation with other systems that support social norms that prevent discrimination, and permanent monitoring and data gathering [49]. It means in reality, that a relocated HEI becomes in practice a center for reintegrating students into a community, which is a long-term process that includes a complex of actions of specialists from different services, involves resources of organizations, offices and communities into work with students, combines training activities with social work and social protection as conditions of successful educational work and reintegration on its basis. Earlier, only general secondary education institutions became centers for helping families with children in a community under conditions of conflict by international standards [50]. Ukrainian experience attests to the need in such work with students and their families on the base of a HEI. This implements 
Table 2. Results of initial diagnostics of comparing life attitudes indicators in students from the occupied territories and the demarcation line (group II) and the students from the safe zone (group I)

\begin{tabular}{|c|c|c|c|c|c|c|c|c|c|}
\hline Life attitude & $\begin{array}{c}\text { Rank } \\
\text { Sum } \\
\text { group I }\end{array}$ & $\begin{array}{c}\text { Rank } \\
\text { Sum } \\
\text { group II }\end{array}$ & $U$ & $z$ & $p$-value & $\begin{array}{c}z \\
\text { adjusted }\end{array}$ & $p$-value & $\begin{array}{l}\text { Valid } N \\
\text { group I }\end{array}$ & $\begin{array}{l}\text { Valid } N \\
\text { group II }\end{array}$ \\
\hline Process & 9637,5 & 12728,5 & 4072,5 & $-3,36$ & 0,0008 & $-3,41$ & 0,006 & 105 & 106 \\
\hline Result & 12095,5 & 10270,5 & 4599,5 & 2,18 & 0,0295 & 2,22 & 0,027 & 105 & 106 \\
\hline Freedom & 9518 & 12848 & 3953 & $-3,63$ & 0,0002 & $-3,68$ & 0,0002 & 105 & 106 \\
\hline Altruism & 11149,5 & 11216,5 & 5545 & 0,04 & 0,966 & 0,04 & 0,9653 & 105 & 106 \\
\hline Egotism & 11197 & 11169 & 5498 & 0,15 & 0,881 & 0,15 & 0,8783 & 105 & 106 \\
\hline Work & 11640 & 10726 & 5055 & 1,15 & 0,251 & 1,17 & 0,2439 & 105 & 106 \\
\hline Money & 10763 & 11603 & 5198 & $-0,83$ & 0,409 & $-0,85$ & 0,3975 & 105 & 106 \\
\hline Power & 11071 & 11295 & 5506 & $-0,13$ & 0,895 & $-0,13$ & 0,8928 & 105 & 106 \\
\hline
\end{tabular}

the idea of the environmental approach through the formation of a student-centered education environment.

The theoretical foundation for students' reintegration at a relocated HEI can therefore be defined as a complex of scientific approaches: the human rights and personality development theory, the sustainable society theory, the safe integration approach, the complex resilience and family-centered approaches (priority of family rights in society and children's rights in a family), the national upbringing theory, the youth participation theory, student-centrism, environmental, competency, multidisciplinary approaches, resource-orientated approach, problem-orientated approach, and social work theories. Therefore, there are numerous multilevel approaches for students' successful reintegration, which enable determining what and how should be done at a relocated HEI.

In the context of reintegration, a HEI begins performing the following new functions in a community concerning students: organizing-and-coordinating, sociodirecting, socio-preventive, socio-educative, outreaching (information-explanatory), consultative, of social protection, and supposes influencing emotive, voluntary, intellectual, physical traits of students; it influences their social wellbeing, life attitudes, values and orientations, social ties resting on the system of various pedagogic and social measures [51-54].

In accordance with theoretical foundations and practices of work with the students from the occupied territories and the demarcation line, this activity by a HEI can be viewed as a system of work with a system-forming factor forming various social conditions at a HEI and community for successful implementation of their right on education and other rights through education, social, and other services in the education process, social work, and social protection in community. These conditions are implemented through special events at a HEI, which can be classified as information-explanatory, socio-educative, psychological, pedagogical, socio-economic, and legal ones. They should be systematic and organizationally coordinated, meet the set goal and tasks.

Correspondently, for a year (February 2019 - January 2020), the mentioned system of work was conducted with students from the occupied territories and the demarcation line. It was implemented through the mentioned events with active coordination by curators of academic groups, heads of departments, directors of institutes, and the deans of faculties, their deputies for socio-educative work, the university students' social service, students' self-governing bodies, the Culture and Leisure Center, the students' trade union organization of the Luhansk Taras Shevchenko National University, and interaction within the free space of the university "Coworking Centre - Creative University", etc [55-57].

Outreach (information-and-explanatory) events supposed:

- providing true information on the events in the east of Ukraine by curators, directors' and deans' deputies on socio-humanitarian work,

- forming safe behavior on the Internet,

- ensuring the right of the university students on obtaining information in Ukrainian language in social networks, on the Internet, official sites, and pages of the university and faculties,

- creating information content on the university site [58] for involving children and youths from the occupied territories to studying at Ukrainian institutions of general secondary and higher education,

- conducting work with their parents as to their children's future,

- consulting on paperwork for entering a HEI, support of applicants from the occupied territories and the demarcation line by the state, state support for internally displaced persons [58, 59].

Socio-education events consisted of educational extracurricular work, involving student youth in the nationalpatriotic education system, organizing their leisure and volunteer activities [42]. The national-patriotic education of students was directed at forming national-patriotic attitude, personality identification with their nation, belief in spiritual strengths and future of the country, the will to work for the good of people; assimilating moral and cultural values [40]. In accordance with the Training-andeducation program of the national-patriotic upbringing of student youth at the Luhansk Taras Shevchenko National University (LNU), the main directions, by which socioeducative events are organized and conducted are: 
- forming national awareness and responsibility for the destiny of Ukraine, bringing up caring attitude to Ukrainian culture,

- strengthening positions of the state language at LNU,

- forming civic responsibility before Ukraine and the society,

- forming a high level of legal culture, respect to the Constitution of Ukraine, laws of Ukraine, state symbols the Coat of arms, the Flag, the Anthem,

- support of the University's traditions and forming university patriotism,

- forming in students civic consciousness and responsibility, facilitating development and support of students' self-government activities,

- forming national-and-cultural traditions of youth in conditions of European integration,

- LNU public organizations' activity in the sphere of national-patriotic education [59].

Organizing of leisure and volunteer activity is closely related to national-patriotic education and supposed:

1) students' participation in the work of the University Culture and Leisure Center's clubs;

2) preparing and running celebration concert programs, and sports events ("the Autumn marathon of strength and spirit", "Cossack games", etc.), theatrical events (the "Great Cossack holiday of Intersession", "The pancake week", "The Ukrainian cuisine holiday", "Dinner party", "Ukrainian Vechornytsi (evening parties)", etc.);

3) facilitating development of volunteer groups' activities, work on university and city improvement, involving students in participating in Ukrainian and international cultural-and-historical trips, charity rallies (the local; "Kindness", "Veterans live next-door"; allUkrainian: "Heart to heart", "To remember. To revive. To preserve", and others), social, intellectual, and artistic meetings, competitions, and projects (reviewcompetition of the university creative teams with accentuation on national patriotism, the Ukrainian culture week, meetings with well-known native artists, current writers, etc.).

Psychological measures included:

- forming in students of critical thinking and safe behavior, stress-resistance, mechanisms of psychologic protection from negative impact of information,

- students' participation in thematic trainings,

- talks and consultations on personal issues, on finding ways of solving conflict situations,

- individual and team work on overcoming a psychological trauma in students who have suffered it.

In psychological events organizing, students' social service and students' self-governing bodies were involved, meetings and talks with specialists in various branches were held in the University's free space "Coworking Centre - Creative University") [57].

Pedagogic measures were directed at:

- orienting students in classes not only at process, but also at getting results from their activities on account of improvement of available resources and optimum organization of their activities,

- taking into account the students' educational needs and peculiarities in their perceiving and cognitive processing of information obtained,

- formation of key competencies that correspond to the principal kinds of a citizen's activities, who is capable of flexible change in means and forms of action, building up their own activity principles and strategies, selfdevelopment motivation, and creative activity development [60].

Socio-economic measures were as follows:

- protection of students' rights and interests by the students' trade union,

- granting students residence in repaired hostels with new furniture, beds, rooms equipped for studying, because living conditions are important for students. Ensuring of adequate social and living conditions is of special importance for a relocated university [61],

- arranging students' meetings with representatives of the International charity organization "SOS Children's Villages",

- organization of mobile brigades' work at different types of education institutions at the demarcation line,

- organization of assistance to students who need financial help and have health problems [42].

The legal measures supposed delivery of thematic lectures, conferences, information-legal classes within the training courses on "History of Ukraine", "Politic studies", "Basics of Law" aimed at obtaining knowledge on the role of the Main Law in Ukrainian state-building; the sittings of the LNU clubs (the clubs of the history of Ukraine, of native language enthusiasts, local history, ethnographic, politic studies, discussing clubs); the information days dedicated to the Day of Europe, European heritage days at the university, driving students youth's attention to the issue of preserving European heritage in the broad sense (the cultural, historic, natural, etc.); discussing issues of the essence and role of the EU in present-day world.

In February 2020, the final students' diagnostics was carried out, results of which, following a comparative analysis, enabled making conclusions as to transformation of social wellbeing and life attitudes in students from the occupied territories and the demarcation line following the implementation of the mentioned reintegration measures in work with them.

In particular, comparing of social wellbeing indicators of students from the occupied territories and the demarcation line, and those who live in safe zones, which at the initial diagnostics stage were lower in the students from the occupied territories (satisfaction with life, interest in 
life, general mood background), attested to the absence of such difference between the groups after the experiment (table 3). This attests to the fact that students from the occupied territories and the demarcation line have reached the same level as that of the students residing in the safe zones.

In order to confirm statistical significance of the transformation in the indicators of satisfaction with life, interest in life, and the general mood background in students from the occupied territories and the demarcation line, results by these indicators obtained prior and following the experiment were compared by means of Wilcoxon's $T$-criterion, and statistical significance of the attained results was confirmed: the satisfaction with life level $T=275,5 ; z=6,07$; $p<0,001$; interest in life $T=406 ; z=3,2 ; p=0,001$; the general mood background $T=88,5 ; z=5,63 ; p<0,001$.

Also, in the mentioned group transformation in life attitudes took place in the scale of "process - result". These indicators levelled with those of the students who lived in safe zones, which is confirmed with results of statistical data procession by Mann-Whitney's $U$-criterion. The obtained data attested to the absence of difference between life needs of students from the occupied territories and the demarcation line and those residing in safe zones (table 4). In order to confirm statistical significance of transformational changes in the indicators of life attitudes to "process", "result", and "freedom" in students from the occupied territories and the demarcation line, the authors compared these attitudes' indicators obtained prior and following the experimental influencing them by means of the Wilcoxon's $T$-criterion, which confirmed the corresponding transformations: "process" $T=44,5, z=5,002$, $p<0,001$; "result" $T=82 ; z=4,82, p<0,001$; "freedom" $T=46, z=5,93, p<0,001$.

Results obtained by the authors coincide with those of the research conducted by S. Savchenko in 2018 concerning the hierarchy of value orientations in the youth from Donbas, which also attested to a raise in the level of attitude to life, freedom, humanism, etc. [25], but the corresponding indicators in the students from the occupied territories and the demarcation line and students from safe zones were not compared in this research. Neither were compared the indicators in these groups concerning their social wellbeing and focus on certain life attitudes.

Therefore, the implementing of the described reintegration measures in a HEI work with students from the occupied territory and the demarcation line facilitated transformational changes concerning their social wellbeing and certain life attitudes and, correspondently, positive changes on the road to their integration into both students' environment of a relocated higher education institution and the Ukrainian space in general.

\section{Conclusions}

1. The research of the state of social wellbeing and life attitudes in students from the east of Ukraine and the demarcation line conducted by the authors of this article attests to the fact that at the stage of students' enrollment to a relocated higher education institution there are certain differences in these indicators compared with students who reside in safe zone. The students in question can be characterized as having lower indicators of satisfaction with life level, interest in life and the general mood background, as well as lower indicators of orientation at process than at result, and higher indicators of the need in exercising the freedom of their choice and behavior, although it should be noted that the freedom attitudes indicators were the highest compared with other life attitudes, which is a characteristic attribute of this period in a person's life.

2. The authors define reintegration of students from the occupied areas and the demarcation line under conditions of a relocated HEI as a long-term process which includes a complex of actions by specialists from different services and subunits of the HEI targeted at forming various conditions for implementing the basic rights and freedoms of students, and combines its activity with social work and social protection, life quality improvement, ensuring students' ties with their families, prioritizes the Ukrainian national idea in its work, involves other organizations', offices' and community's resources in reintegration work for achievement of the common and far-reaching goal of restoring territorial, economic, social, and political unity of the country and population, of overcoming disunity and conflicts. The theoretical foundations of such reintegration is a complex of scientific approaches: the theory of human rights and personality development, the sustainable society theory, the safe integration approach, the complex, the resilience, the family-centered approaches, the national education theory, the theory of youth participation, studentcentrism, the environmental, the resource-oriented, the competency, the multidisciplinary approaches, social work approaches, and the problem-oriented approach. Therefore, there are multilevel and different sciences' approaches to students' successful reintegration at a relocated HEI and in a new community.

3. The efficient measures of integrating the students from the occupied areas and the demarcation line zone in a relocated HEI were: outreach (information-and-explanatory), socio-educational, psychological, pedagogical, socio-economic, and legal ones, which should be systematic, organizationally coordinated, correspond to the set goal, and be implemented in a complex, with the national education as a priority.

4. The use of the described measures under conditions of a relocated HEI is efficient because it ensures transformational changes related to overcoming the imbalance between the social wellbeing indicators (satisfaction with life level, interest in life, general mood background) and life attitudes (focus on process, result, freedom) in students from the occupied 
Table 3. Results of the final diagnostics of comparing social wellbeing indicators in students from the occupied territories and the demarcation line (group II) and students from safe zones (group I)

\begin{tabular}{|c|c|c|c|c|c|c|c|c|c|}
\hline Indicator & $\begin{array}{c}\text { Rank } \\
\text { Sum } \\
\text { group I }\end{array}$ & $\begin{array}{c}\text { Rank } \\
\text { Sum } \\
\text { group II }\end{array}$ & $U$ & $z$ & $p$-value & $\begin{array}{c}z \\
\text { adjusted }\end{array}$ & $p$-value & $\begin{array}{l}\text { Valid } N \\
\text { group I }\end{array}$ & $\begin{array}{l}\text { Valid } N \\
\text { group II }\end{array}$ \\
\hline \multicolumn{10}{|l|}{ Satisfaction with } \\
\hline life level & 11061,5 & 11304,5 & 5496,5 & $-0,15$ & 0,88 & $-0,15$ & 0,88 & 105 & 106 \\
\hline Interest in life & 11227,5 & 11138,5 & 5467,5 & 0,22 & 0,83 & 0,22 & 0,82 & 105 & 106 \\
\hline General mood & & & & & & & & & \\
\hline background & 11294,5 & 11071,5 & 5400,5 & 0,37 & 0,71 & 0,38 & 0,7 & 105 & 106 \\
\hline
\end{tabular}

Table 4. Results of the final diagnostics of comparing the life attitudes indicators in students from the occupied territories and the demarcation line (group II) and students from safe zone (group I)

\begin{tabular}{|c|c|c|c|c|c|c|c|c|c|}
\hline Life attitude & $\begin{array}{c}\text { Rank } \\
\text { Sum } \\
\text { group I }\end{array}$ & $\begin{array}{c}\text { Rank } \\
\text { Sum } \\
\text { group II }\end{array}$ & $U$ & $z$ & $p$-value & $\begin{array}{c}z \\
\text { adjusted }\end{array}$ & $p$-value & $\begin{array}{l}\text { Valid } N \\
\text { group I }\end{array}$ & $\begin{array}{l}\text { Valid } N \\
\text { group II }\end{array}$ \\
\hline Process & 10959,5 & 11406,5 & 5394,5 & $-0,38$ & 0,7 & $-0,39$ & 0,69 & 105 & 106 \\
\hline Result & 10928,5 & 11437,5 & 5363,5 & $-0,45$ & 0,65 & $-0,46$ & 0,64 & 105 & 106 \\
\hline Freedom & 10868 & 11498 & 5303 & $-0,59$ & 0,56 & $-0,6$ & 0,55 & 105 & 106 \\
\hline Altruism & 11179,5 & 11186,5 & 5505,5 & 0,11 & 0,91 & 0,11 & 0,91 & 105 & 106 \\
\hline Egotism & 11495 & 10871 & 5200 & 0,82 & 0,4 & 0,84 & 0,5 & 105 & 106 \\
\hline Work & 10670,5 & 11695,5 & 5105,5 & $-1,03$ & 0,3 & $-1,04$ & 0,29 & 105 & 106 \\
\hline Money & 11515 & 10851 & 5180 & 0,87 & 0,4 & 0,89 & 0,37 & 105 & 106 \\
\hline Power & 11575,5 & 10790,5 & 5119,5 & 1 & 0,3 & 1,03 & 0,3 & 105 & 106 \\
\hline
\end{tabular}

territories and the demarcation line versus those residing in the safe zone, which facilitates reintegration of students from the occupied territories and the demarcation line into student environment of a relocated higher education institution and the Ukrainian space.

The authors consider organizing further work in studying the perspectives of youth concerning future employment and their activity and initiative development in terms of communities' evolvement in the east of Ukraine.

\section{References}

[1] V. Semykolenov, Naukovyi visnyk Chernivetskoho universytetu. Filosofiia. 663-664, 88 (2013)

[2] O.M. Tseliakova, Humanitarnyi visnyk ZDIA 62, 50 (2015)

[3] M. Alyohin, Nova paradyhma. 132, 153 (2017)

[4] D. S. Van, Ph.D. thesis, V. N. Karazin Kharkiv National University (2016)

[5] L. Kulikov, in Obschestvo i politika (Society and politics), edited by V.Y. Bolshakov (Yzd-vo S.Peterburhskoho un-ta, Sankt-Peterburh, 2000), pp. 476-510

[6] R. Shamionov, Psihologiya sotsialnogo povedeniya lichnosti (Psychology of a personality's social behavior) (Nauka, Saratov, 2009)

[7] I.M. Trubavina, in Hibrydna viina na Skhodi Ukrainy $v$ mizhdystsyplinarnomu vymiri: vytoky, realii, perspektyvy reintehratsii (Hybrid war in eastern Ukraine in an interdisciplinary dimension: origins, realities, prospects for reintegration), edited by O.K. V.S. Kurylo, S.V. Savchenko (DZ "LNU imeni Tarasa Shevchenka", Starobilsk, Starobilsk), pp. 320-342

[8] V. Krutiy, Ph.D. thesis, Instytut derzhavy i prava im. V. M. Koretskoho NAN Ukrainy (2018)

[9] A. Lun'ova, Osvita ditei z okupovanykh terytorii: reintehratsiia, yaka nabuvaie zmistu (Educating children from the occupied territories: reintegration that makes sense) (2020), https://zmina.info/columns/ osvita-ditej-z-okupovanyh-terytori-/ reintegracziya-yaka-nabuvaye-zmistu/

[10] Pro vnesennia zmin do Zakonu Ukrainy "Pro vyshchu osvitu" shchodo osoblyvostei vstupu do zakladiv vyshchoi osvity osib z tymchasovo okupovanykh terytorii Avtonomnoi Respubliky Krym ta mista Sevastopolia, Donetskoi ta Luhanskoi oblastei (On introduction of changes to the Law of Ukraine "On Higher Education" as to peculiarities of enrollment of individuals from temporally occupied territories of the Autonomous Republic of Crimea, the city of Sebastopol, Donetsk and Luhansk areas to higher education institutions) Verkhovna Rada of Ukraine, Zakon Ukrainy 744-ix, 03.07.2020 (18 Aug 2020), https://zakon.rada.gov.ua/laws/show/ 744-20\#Text

[11] 1600 vstupnykiv $z$ Donbasu ta $265-z$ Krymu tsohorich vstupyly do ukrainskykh vyshiv za sproshchenoiu protseduroiu, tse naibilshyi pokaznyk za ostanni 4 roky. Ministerstvo osvity i nauky Ukrainy $\quad(1600$ applicants from Donbas and 265 from Crimea 
have entered this year to Ukrainian higher education institutions by simplified procedure, which is the biggest indicator in the last 4 years). (Ministry of Education and Science of Ukraine, 2019) (25 Aug 2020), http://surl.1i/nire

[12] Za 3 roky kilkist vstupnykiv $z$ okupovanykh terytorii cherez osvitni tsentry "Krym-Ukraina" $i$ "Donbas-Ukraina" zrosla maizhe vdvichi. Ministerstvo osvity i nauky Ukrainy (in the past 3 years the number of applicants from the occupied territories through the "Crimea-Ukraine" and "Donbas-Ukraine" education centers has increased nearly twofold). (Ministry of Education and Science of Ukraine, 2018) (26 Aug 2020), http://surl.li/nira

[13] S. Horbatiuk, Visnyk Natsionalnoi akademii derzhavnoho upravlinnia pry Prezydentovi Ukrainy 1, 229 (2009)

[14] V. Gil-Rivas, E. Holman, R. Silver, Appl. Developmental Sci 8, 130 (2004)

[15] R.P. Kilmer, V. Gil-Rivas, S.J. Hardy, in Supporting and educating traumatized students: A guide for school-based professionals, edited by R.H. E. Rossen (Oxford University Press, 2013), pp. 229250

[16] G. Kerestes, International J. of Behavioral Development 30, 227-239 (2006)

[17] L.B. Saupe, K. Gößmann, C. Catani, F. Neuner, Front. Psychol. (2019)

[18] R. Seginer, International J. of Behavioral Development pp. 272-282 (2008)

[19] L. Stark, M. Wessells, D. King, D. Lamin, S. Lilley, A grounded approach to the definition of populationbased, child protection and wellbeing outcome areas (Interagency Learning Initiative on CommunityBased Child Protection Mechanisms and Child Protection Systems, London, 2012)

[20] A. Honwana, IDS Bulletin 40, 63 (2009)

[21] A. Bryden, V. Scherrer, eds., Disarmament, demobilization, and reintegration and security sector reform: Insights from Un experience in Afghanistan, Burundi, and Central African Republic (Lit Verlag, Berlin, 2012)

[22] A. Giustozzi, ed., Post-conflict disarmament, demobilization, and reintegration: Bringing state-building back in (Ashgate Publishing, Surrey, UK, 2012)

[23] M. Humphreys, J. Weinstein, J. of Conflict Resolution 51, 531 (2007)

[24] D.A. Matyuhin, Visnyk NTUU “KPI”. Politolohiia. Sotsiolohiia. Pravo. 3/4, 88 (2016)

[25] S.V. Savchenko, Education and Pedagogical Sciences 168, 5 (2018)

[26] N.O. Kurylo, Visnyk Luhan. nats. un-tu imeni Tarasa Shevchenka. Ped. nauky 329, 16-25 (2019)

[27] Intensyfikatsiia vplyvu vchyteliv luhanskoi oblasti na protsesy prymyrennia $i$ vstanovlennia myru. Rezultaty 1 etapu sotsiolohichnoho doslidzhennia (Intensification of influence of teachers of Luhansk region on the processes of reconciliation and peacebuilding. Results of the 1st stage of the social research)) (2020), http://luteachrp.luguniv. edu.ua/?p=408

[28] I.M. Trubavina, Visnyk Luhan. nats. un-tu imeni Tarasa Shevchenka. Ped. nauky 137, 115 (2018)

[29] O. Karaman, in Innovatsii pedahohichnoi osvity $v$ umovakh vyklykiv sohodennia (Innovations of pedagogical education in the conditions of today's challenges), edited by S.Y. Kharchenko (Derzh. zakl. "Luhan. nats. un-t imeni Tarasa Shevchenka", 2019), pp. 156-178

[30] O.L. Karaman, Y.I. Yurkiv, Visnyk Luhan. nats. un-tu imeni Tarasa Shevchenka. Ped. nauky 324, 14 (2019)

[31] Propozytsii do polityky shchodo vrehuliuvannia konfliktu na tymchasovo nepidkontrolnykh terytoriiakh na skhodi Ukrainy (Proposals to the policies of concerning solving the conflict on temporally uncontrolled territories in the east of Ukraine) (2017), https://bit. 1y/3csPb4C

[32] D.Y. Raygorodskiy, Prakticheskaya psihodiagnostika. Metodiki $i$ testyi (Practical psychodiagnostics. Methodologies and tests) (Izdatelskiy Dom "BAHRAH-M, Samara, 2001)

[33] N. Panina, in LifeLine i drugie novyie metodyi psihologii zhiznennogo puti (LifeLine and other new methods of life path psychology) (Progress-Kultura", Moskva), p. 107-114

[34] S.D. Maksymenko, Zahalna psykholohiia (General Psychology) (Nova Knyha, Vinnytsia, 2004)

[35] T.G. Yermakova, Grani 20, 89 (2017)

[36] T.E. Petrova, Sotsyolohyia studenchestva v Rossyy. Etapyi y zakonomernosty stanovlenyia (Students' sociology in Russia. The stages and regularities in formation) (Belveder, Sankt-Peterburg, 2000)

[37] Y. Krupets, Sotsiolog. Issledovaniya 4, 106 (2003)

[38] O. Shapran, Visnyk Natsionalnoi akademii derzhavnoho upravlinnia pry Prezydentovi Ukrainy 2, 289 (2003)

[39] Kafedra sotsialnoi pedahohiky. Luhanskyi natsionalnyi universytet imeni Tarasa Shevchenka (he Departmentt of social pedagogy. Luhansk Taras Shevchenko National University) (2020), http://luguniv.edu.ua/?page_id= 16387.

[40] Luhanskyi natsionalnyi universytet imeni Tarasa Shevchenka. Sohodennia (The Luhansk Taras Shevchenko National University. Present-day) (2020), http://luguniv.edu.ua/ ?page_id=31

[41] Stratehiia rozvytku Derzhavnoho zakladu "Luhanskyi natsionalnyi universytet imeni Tarasa Shevchenka 2019-2025 roky" (The Strategy of development of Luhansk Taras Shevchenko National University state institution for 2019-2025), https: //bit.ly/3vffvrD 
[42] Zvit rektora Savchenka Serhiia Viktorovycha na spilnomu zasidanni vchenoi rady ta konferentsii trudovoho kolektyvu Derzhavnoho zakladu "Luhanskyi natsionalnyi universytet imeni Tarasa Shevchenka” za period z sichnia 2019 roku po sichen 2020 roku : informatsiini materialy (The Account of Rector Savchenko Serhiy Victorovych at the joint meeting of the Scientific Council and the collective of Luhansk Taras Shevchenko National University state institution for the period between jan 2019 and jan 2020: information materials) (2020), https://bit.1y/3etCM3j

[43] I. Halyan, Naukovyi visnyk MNU imeni V. O. Sukhomlynskoho. Psykholohichni nauky 16, 27 (2016)

[44] Y. Balashov, E.M. Balashov, Nauk. zapysky Nats. un-tu "Ostrozka akademiia". Psykhol. i ped. 30, 8 (2014)

[45] A. Kuznetsov, Bolshoy tolkovyiy slovar russkogo yazyika (The large explanatory dictionary of Russian language) (Norint, Sankt-Peterburg, 1998)

[46] Rekomendatsi i Reintegratsiya naseleniya, postradavshego ot konflikta na donbasse $i$ vosstanovlenie spravedlivogo mira: tekuschee sostoyanie i prioritetyi na buduschee (Recommendations on reintegrating the population who suffered from the conflict at Donbas and restoration of the just peace: current state of affairs and future priorities) (2019), https: //bit.1y/3etCM3j

[47] V. Lupatsiy, O. Saakyan, Y. Tyschenko, Pozytsiinyi dokument shchodo instytutsiinoho zabezpechennia polityky bezpechnoi reintehratsii na Skhodi Ukrainy (Position Document concerning institutional securing of safe reintegration policies in the east of Ukraine) (FOP “Kharchenko V.O.”, Kyiv, 2020)

[48] Konventsiia pro prava dytyny (The Convention on Children's Rights) (1989), https://zakon. rada.gov.ua/laws/show/995_ Q21\#Text

[49] Rukovodyaschie ukazaniya po reintegratsii detey (guidelines on children's reintegration) (2016), https://bit.1y/3qDG6en

[50] K. Levchenko, V. Panok, I. Trubavina, Sotsialnopedahohichna ta psykholohichna dopomoha simiam $z$ ditmy $v$ period viiskovoho konfliktu (Sociopedagogic and psychological assistance to families with children during the military conflict) (Ahentstvo "Ukraina", Kyiv, 2015)

[51] I.O. Lepekha, M.P. Khomenko, O.V. Nevmerzhytskyi, Vykhovna robota u vyshchykh navchalnykh zakladakh. Z dosvidu vykladachiv ahrarnykh vyshchykh navchalnykh zakladiv (Upbringing work at higher education institutions. Experience of agrarian higher education teachers) (Ahroosvita, Kyiv, 2015)

[52] V.S. Tserklevych, Y.M. Kyryliuk, Na dopomohu kuratoru akademichnoi hrupy (In assistance to an academic group curator) (KhKTEI, Khmelnytskyi, 2015)

[53] L. Yaroshchuk, Teoriia i metodyka vykhovannia (Theory and methodology of education) (Berdiansk, 2019)

[54] I. Trubavina, Metodychni rekomendatsii do orhanizatsii provedennia informatsiino-roziasniuvalnoi sotsialnoi roboty dlia vnutrishno peremishenykh osib (Methodology recommendations concerning organizing of information-and-explanatory social work for internally displaced persons) (Berdiansk, 2017)

[55] Luhanskyi natsionalnyi universytet imeni Tarasa Shevchenka. Obmin dosvidom (Luhansk Taras Shevchenko National University. Experience exchange) (2019), http://luguniv.edu.ua/?p= 47107

[56] Luhanskyi natsionalnyi universytet imeni Tarasa Shevchenka. Profspilkova orhanizatsiia studentiv (Luhansk Taras Shevchenko National University. Students' trade union organization) (2020), http: //luguniv.edu.ua/?page_id=37

[57] Luhanskyi natsionalnyi universytet imeni Tarasa Shevchenka. Studentska sotsialna sluzhba (Luhansk Taras Shevchenko National University. Students' social service) (2020), http://luguniv.edu.ua/ ?page_id=4549

[58] Luhanskyi natsionalnyi universytet imeni Tarasa Shevchenka. Vstup za prohramoiu "Donbas Ukraina" ta "Krym - Ukraina" dlia abituriientiv zi skhodu Ukrainy ta Krymu (Luhansk Taras Shevchenko National University. Enrolment by the "Donbas - Ukraine" and "Crimea - Ukraine" programs for applicants from the east of Ukraine and Crimea) (2020), http://luguniv.edu.ua/ ?page_id=41962

[59] Osvitno-prosvitnytska prohrama natsionalnopatriotychnoho vykhovannia studentskoi molodi Luhanskoho natsionalnoho universytetu imeni Tarasa Shevchenka (Training-and-education program of national upbringing of student youth at Luhansk Taras Shevchenko National University) (2015), https://bit.1y/3ew4BrC

[60] Y. Zavgorodnya, Visnyk Luhan. nats. un-tu imeni Tarasa Shevchenka. Ped. nauky 306, 70 (2017)

[61] Luhanskyi natsionalnyi universytet imeni Tarasa Shevchenka. vidkryttia navchalnoho korpusu ta hurtozhytku (Luhansk Taras Shevchenko National University. the opening of the lecture building and students' hostel) (2019), http://luguniv.edu.ua/ $? \mathrm{p}=41605$ 